\title{
Nutritional Status of under 5 Year-Old Children and its Relationship with Maternal Nutrition Knowledge in Weeraketiya DS division of Sri Lanka
}

\author{
T.D.R. Peiris and D.G.N.G. Wijesinghe ${ }^{1}$ \\ Postgraduate Institute of Agriculture \\ University of Peradeniya \\ Peradeniya, Sri Lanka
}

\begin{abstract}
The present study was conducted in the Weeraketiya divisional secretariat division of the Hambanthota district of Sri Lanka to determine the nutritional status of preschool children and to identify maternal knowledge regarding micronutrients and child feeding practices. The study sample consisted of 1102 families having 1219 children below 5 years of age. A population based cross-sectional study was carried out. An intervieweradministered, pre-tested questionnaire was used to collect information related to nutritional knowledge of the mother/caregiver during household visits. Heights and weights of the children were measured using properly calibrated equipment. Trained volunteers were used for taking measurements and administering the questionnaire. Nutritional status was determined using Epi Info software and data analysis was performed using the SPSS software. The prevalence of stunting $(11.8 \%)$ in this community was lower than the national prevalence of stunting (18\%). Prevalence of wasting (42.7\%) and underweight (41.2\%) was higher than national prevalence (15\% and $21.6 \%$, respectively). Wasting increased with the age and was the highest in the 49-60 month age group (50.2\%). Prevalence of low birth weight $(14.5 \%)$ was lower than the National average figure of $17.1 \%$. The low birth weight had a positive relationship with the current undernutrition status of the child. Based on WHO criteria, Weeraketiya has a very high prevalence of wasting and underweight and low prevalence of stunting. Maternal educational status was not associated with the prevalence of undernutrition. Breastfeeding and complementary feeding practices were satisfactory but maternal knowledge regarding micronutrients, child feeding during illnesses and management of diarrhoea was poor. Low birth weight shared a relationship with the prevalence of wasting and underweight condition of the children in this community.
\end{abstract}

\section{INTRODUCTION}

Child malnutrition is the most pressing problem of the world, damaging both children and the nations (de Onis et al., 2000). Significant proportion of deaths of young children worldwide is due to malnutrition and efforts to reduce malnutrition should be a policy priority (Caulifield et al., 2004). The level of childhood malnutrition is exceptionally high in South Asia, ranging from 45-48\% in India, Bangladesh and Nepal, 38\% in Pakistan and 30\% in Sri Lanka. The underlying causes of malnutrition vary from poverty, low levels of education and poor access to health services (Khan and Bano, 2007). 
Undernutrition caused by protein energy malnutrition and micronutrient (iron, iodine and vitamin A) deficiencies among children, have been identified as major nutritional problems in Sri Lanka (Wikramanayake, 1997). Anthropometric indices represent the cumulative effect of access to food, nutrition practices, health, education of parents and environmental health conditions. Therefore, the nutritional status is a powerful indicator of nutrition security and well being of an individual and reflects the nutritional and poverty situation of a household. The nutritional status of pre-school children is a sensitive indicator, because children are most vulnerable to nutritional imbalances.

According to Sri Lanka Demographic and Health Survey (2006/7), $21.6 \%$ of children under 5 years in Sri Lanka were underweight, $15 \%$ children were wasted and $18 \%$ children were stunted (Department of Census and Statistics in collaboration with Ministry of Health, 2008). Although inadequate food intake is a basic cause of undernutrition, several other factors such as living standards, water and sanitation, birth weight, birth interval and parity, weaning practices and mother's education have been identified as contributing to incidence of malnutrition among the preschool children.

This study was conducted to determine the nutritional status of children under-5 years of age in all 26 GN (Grama Niladhari) divisions of the Weeraketiya Divisional Secretariat (DS) division and to evaluate the knowledge of the mother with regard to micronutrients and child feeding practices including breastfeeding, complementary feeding and feeding during illness.

\section{MATERIALS AND METHODS}

\section{Location of the Study:}

This study was conducted during October-November 2007 in Weeraketiya DS division in the Hambanthota district which belongs to the Dry Zone of Sri Lanka. It has 123 villages comprising $85 \mathrm{GN}$ divisions. The total population in the area was 62,201 and they belonged to 1322 families.

\section{Study Sample:}

The study sample comprised all households having children 0-5 years of age from all 26 GN divisions of the Weerakatiya DS division (1123 households, 1232 children).

\section{Methodology:}

A population based cross-sectional study was designed. Heights and weights of the children were measured following standard methods and using properly calibrated equipments (Salter 920/986 digital weighing scale, Seca 364 Infant weighing scale, Seca 210 length measuring mat, Seca 210 mechanical height measuring tape and standard height board) to assess the nutritional status. The birth weight was taken from the Child Health and Development Record (CHDR) card. The services of trained volunteers were sought in administering the questionnaire and taking anthropometric measurements. The inter-individual variability of measurements was minimized by ample training given prior to the survey. The accuracy and reliability of measurements were verified by observing a random sample in the field while taking measurements. 
An interviewer-administered pre-tested questionnaire was used to collect information related to knowledge regarding major nutritional problems prevailing in the community and child feeding practices of mothers, during household visits.

\section{Data Analysis:}

Data was coded and entered into a computer database, summarized and presented descriptively. Z-scores were calculated for height-for-age (HAZ), weight-for-height (WHZ) and weight-for-age (WAZ) using Epi Info software. Prevalence of stunting, wasting and underweight was determined using <-2 of HAZ, WHZ and WAZ, respectively of the CDC/NCHS (2000) reference standards. The figures therefore represent moderate and severe undernutrition for each category. Relationships among nutritional variables, birth weight and parental education were analyzed using Spearman's Chi square test using SPSS software.

\section{RESULTS AND DISCUSSION}

\section{Characteristics of the study sample}

The study sample consisted of 1219 children aged 0-5 years with a similar distribution of boys and girls (boys 625, girls 594). The distribution of the sample according to the age and gender is given in Table 1 .

Table 1. Distribution of study sample by age and gender

\begin{tabular}{lcccccc}
\hline $\begin{array}{l}\text { Age } \\
\text { (months) }\end{array}$ & $\mathbf{0 - 6}$ & $\mathbf{7 - 1 2}$ & $\mathbf{1 3 - 2 4}$ & $\mathbf{2 5 - 3 6}$ & $\mathbf{3 7 - 4 8}$ & $\mathbf{4 9 - 6 0}$ \\
\hline Boys & 57 & 76 & 137 & 117 & 132 & 106 \\
Girls & 46 & 57 & 130 & 136 & 124 & 101 \\
Total & 103 & 133 & 267 & 253 & 126 & 207 \\
\hline
\end{tabular}

\section{Nutritional status}

The data on overall nutritional status of the sample is given in Table 2. Of the children under-5 years old $(n=1219)$, only $41 \%$ had satisfactory nutritional status and $59 \%$ had some form of malnutrition. Majority of them were wasted (42.7\%). The prevalence of underweight and stunting among these children was $41.2 \%$ and $11.8 \%$ respectively. There was no sgnificant gender difference in the prevalence of undernutrition. The prevalence of wasting and underweight was higher, and stunting was lower than the national average values. According to the classification criteria for assessing severity of growth deficits by prevalence ranges among children under 5 years of age (de Onis and Blossner, 1997) the prevalence of wasting and underweight could be ranked as 'very high' and stunting could be ranked as 'low' in the Weeraketiya DS division. 
Table 2. Nutritional status of children (0-60 months) by gender

\begin{tabular}{lllllll}
\hline \multirow{2}{*}{ Nutrition Category } & \multicolumn{2}{c}{ Male } & \multicolumn{2}{c}{ Female } & \multicolumn{2}{c}{ Total } \\
\cline { 2 - 7 } & \multicolumn{1}{c}{ No } & \multicolumn{1}{c}{$\%$} & \multicolumn{1}{c}{ No } & \% & No & \% \\
\hline Stunting & 83 & 13. & 61 & 10.3 & 144 & 11.8 \\
Wasting & 263 & 42.1 & 258 & 43.4 & 521 & 42.7 \\
Underweight & 258 & 41.3 & 244 & 41.1 & 502 & 41.2 \\
Overweight/Obese & 12 & 1.9 & 17 & 2.9 & 29 & 2.4 \\
Normal & 254 & 40.6 & 250 & 42.1 & 504 & 41.3 \\
Total & 625 & 51.3 & 594 & 48.7 & 1219 & 100 \\
\hline
\end{tabular}

* Stunting, wasting and underweight were categorized as $\leq-2$ of HAZ, WHZ and WAZ respectively of the CDC/NCHS 2000 reference values. Figures therefore represent moderate and severe undernutrition for each category. Overweight or obese were categorized as $\mathrm{WAZ} \geq 1$.

Table 3 shows a breakdown [percentage, mean and 95\% confidence interval (CI)] of Zscores for mild, moderate and severe forms of stunting, underweight and wasting, and also for the normal group under each indicator. The data for overweight or obese (weight/age zscore $\geq 1.0$ ) children are also presented.

Most of the stunted children were either mildly (26\%) or moderately (8\%) stunted and severely stunted children were very low (4\%). However, a considerable amount of severe malnutrition was found among wasted (19\%) and underweight (14\%) children in addition to mild- and moderate malnutrition.

Table 3. Breakdown of z-scores for different nutritional categories

\begin{tabular}{|c|c|c|c|c|c|c|}
\hline \multirow{2}{*}{$\begin{array}{l}\text { Degree of } \\
\text { Nutrition }\end{array}$} & \multicolumn{2}{|c|}{$\begin{array}{c}\text { Stunting } \\
\text { (height-for-age) }\end{array}$} & \multicolumn{2}{|c|}{$\begin{array}{c}\text { Underweight } \\
\text { (weight-for-age) }\end{array}$} & \multicolumn{2}{|c|}{$\begin{array}{c}\text { Wasting } \\
\text { (Weight-for-height) }\end{array}$} \\
\hline & $\%$ & $\begin{array}{c}\text { mean z-score } \\
(95 \% \text { C.I. })\end{array}$ & $\%$ & $\begin{array}{c}\text { mean z-score } \\
(95 \% \text { C.I. })\end{array}$ & $\%$ & $\begin{array}{c}\text { mean z-score } \\
(95 \% \text { C.I. })\end{array}$ \\
\hline $\begin{array}{l}\text { Severely } \\
\text { Malnourished }\end{array}$ & 3.7 & $\begin{array}{c}-4.50 \\
(-4.95 \text { to }-4.04)\end{array}$ & 13.7 & $\begin{array}{c}-3.80 \\
(-3.91 \text { to }-3.68)\end{array}$ & 19.0 & $\begin{array}{c}-3.92 \\
(-4.06 \text { to }-3.78)\end{array}$ \\
\hline $\begin{array}{l}\text { Moderately } \\
\text { Malnourished }\end{array}$ & 8.2 & $\begin{array}{c}-2.40 \\
(-2.45 \text { to }-2.35)\end{array}$ & 27.5 & $\begin{array}{c}-2.47 \\
(-2.50 \text { to }-2.44)\end{array}$ & 23.7 & $\begin{array}{c}-2.48 \\
(-2.51 \text { to }-2.44)\end{array}$ \\
\hline $\begin{array}{l}\text { Mildly } \\
\text { Malnourished }\end{array}$ & 25.9 & $\begin{array}{c}-1.43 \\
(-1.46 \text { to }-1.40)\end{array}$ & 29.9 & $\begin{array}{c}-1.53 \\
(-1.56 \text { to }-1.50)\end{array}$ & 27.4 & $\begin{array}{c}-1.50 \\
(-1.53 \text { to }-1.47)\end{array}$ \\
\hline $\begin{array}{l}\text { Adequately } \\
\text { Nourished }\end{array}$ & 62.2 & $\begin{array}{c}0.27 \\
(0.17 \text { to } 0.36)\end{array}$ & 26.5 & $\begin{array}{c}-0.25 \\
(-0.31 \text { to }-0.19)\end{array}$ & 29.9 & $\begin{array}{c}-0.05 \\
(-0.14 \text { to } 0.04)\end{array}$ \\
\hline $\begin{array}{l}\text { Overweight } \\
\text { Or obese }\end{array}$ & & N/A & 2.4 & $\begin{array}{c}-1.53 \\
(1.46 \text { to } 2.15) \\
\end{array}$ & & N/A \\
\hline
\end{tabular}

The prevalence of undernutrition by age indicates that overall undernutrition increases with age in both sexes (Table 4). The prevalence of wasting, which was the biggest problem in this community, was considerably high already during the first 6 months of age in both sexes (27\%) and after the first year it almost doubled. The prevalence of underweight was comparatively low (8\%) during the first 6 months but increased almost 4-folds after the first 6 months and doubled further after one year. The stunting, on the other hand, was very low 
(4\%) in the first 6 months and it also increased more than 2-fold after one year, in both sexes. All three forms of undernutrition showed higher values after the age of 1 year, in both sexes. Wasting was the most striking form of undernutrition in either sex, and its prevalence was around 50\% in older children (49-60 months).

Table 4. Prevalence of undernutrition in children by age and gender

\begin{tabular}{lcccccc}
\hline Age (months) & $\mathbf{0 - 6}$ & $\mathbf{7 - 1 2}$ & $\mathbf{1 3 - 2 4}$ & $\mathbf{2 5 - 3 6}$ & $\mathbf{3 7 - 4 8}$ & $\mathbf{4 9 - 6 0}$ \\
\hline Stunting (\%) & & & & & & \\
Boys & 5.3 & 7.9 & 12.4 & 17.9 & 16.7 & 13.2 \\
Girls & 2.2 & 1.8 & 9.2 & 16.9 & 9.7 & 11.9 \\
Total & 3.9 & 5.3 & 10.9 & 17.4 & 13.3 & 12.6 \\
Wasting (\%) & & & & & & \\
Boys & 28.1 & 22.4 & 43.1 & 42.7 & 50.8 & 50.9 \\
Girls & 26.1 & 28.1 & 44.6 & 47.8 & 46.0 & 49.5 \\
Total & 27.2 & 24.8 & 43.8 & 45.5 & 48.4 & 50.2 \\
Underweight (\%) & & & & & & \\
Boys & 5.3 & 31.6 & 51.1 & 47.9 & 41.7 & 47.2 \\
Girls & 10.9 & 21.1 & 53.8 & 48.5 & 36.3 & 45.5 \\
Total & 7.8 & 27.1 & 52.4 & 48.2 & 39.1 & 46.4 \\
\hline
\end{tabular}

\section{Prevalence of low birth weight}

The percentage low birth weight $(14.5 \%)$ reported in the present study is lower than the national average figure of $17 \%$ (Annual Health Bulletin, 2006). Gender comparison revealed that girls had a slightly higher prevalence of low birth weight than boys (Table 5).

Table 5. Birth weight of the under-5 children in the study sample

\begin{tabular}{lcccccc}
\hline \multirow{2}{*}{$\begin{array}{l}\text { Birth weight } \\
\text { category }\end{array}$} & \multicolumn{2}{c}{ Boys } & \multicolumn{2}{c}{ Girls } & \multicolumn{2}{c}{ Total } \\
\cline { 2 - 7 } No & \% & No & \% & No & \% \\
\hline Normal & 548 & 87.7 & 494 & 83.2 & 1042 & 85.5 \\
Low & 77 & 12.3 & 100 & 16.8 & 177 & 14.5 \\
Total & 625 & 100 & 594 & 100 & 1219 & 100 \\
\hline
\end{tabular}

Birth weight has a direct relationship with the current nutritional status of the child as shown in Table 6. Wasting and underweight were significantly high among children with low birth weights.

\section{Education of the parents}

The maternal educational status in this community was satisfactory as the majority (62\%) of mothers had studied up to G.C.E. (O/L) and another 19\% had studied up to G.C.E. (A/L). Also there were mothers with university degrees (3.0\%). Mothers with no schooling (1.5\%) or only primary education $(7.3 \%)$ were very small. The educational status of the father was no better than that of the mother (Table 7).

When the educational level of the parents was compared with the nutritional status of the child, no significant relationship was found between parents' educational level and the nutritional status of the child (Table 8). 
Peiris and Wijesinghe

Table 6. Birth weight and the current nutritional status of the child

\begin{tabular}{|c|c|c|c|}
\hline \multirow{2}{*}{$\begin{array}{l}\text { Nutritional } \\
\text { Indicator* }\end{array}$} & \multicolumn{2}{|c|}{ Birth weight } & \multirow[t]{2}{*}{ Probability } \\
\hline & Low $^{\#}$ & Normal & \\
\hline \multicolumn{4}{|l|}{ HAZ } \\
\hline Normal & $136(85)$ & $833(88)$ & \\
\hline Stunted & $24(15)$ & 109 (12) & 0.218 \\
\hline \multicolumn{4}{|l|}{ WHZ } \\
\hline Normal & $59(37)$ & $563(60)$ & \\
\hline Wasted & $101(63)$ & $379(40)$ & $<0.0001$ \\
\hline \multicolumn{4}{|l|}{ WAZ } \\
\hline Normal & $66(41)$ & $577(61)$ & \\
\hline Underweight & $94(59)$ & 365 (39) & $<0.0001$ \\
\hline
\end{tabular}

Table 7. Educational level of the parents in the study sample

\begin{tabular}{lcccc}
\hline \multirow{2}{*}{ School grade } & \multicolumn{2}{c}{ Mother } & \multicolumn{2}{c}{ Father } \\
\cline { 2 - 5 } & No. & \% & No. & \% \\
\hline No schooling & 17 & 1.5 & 16 & 1.5 \\
Primary (1-5) & 80 & 7.3 & 156 & 14.2 \\
$6-8$ & 82 & 7.4 & 195 & 17.7 \\
$9-11$ & 684 & 62.1 & 552 & 50.1 \\
$12-13$ & 206 & 18.7 & 164 & 14.9 \\
Tertiary & 33 & 3.0 & 19 & 1.7 \\
Total & 1102 & 100 & 1102 & 100 \\
\hline
\end{tabular}

Table 8 Parents' education and the nutritional status of the child

\begin{tabular}{|c|c|c|c|c|c|c|c|}
\hline \multirow{3}{*}{ Variable } & \multirow{3}{*}{$\begin{array}{c}\text { Total } \\
\text { No. }\end{array}$} & \multicolumn{6}{|c|}{ Prevalence of undernutrition ${ }^{\#}$} \\
\hline & & \multicolumn{2}{|c|}{ Stunting } & \multicolumn{2}{|c|}{ Wasting } & \multicolumn{2}{|c|}{ Underweight } \\
\hline & & No. & $\%$ & No. & $\%$ & No. & $\%$ \\
\hline \multicolumn{8}{|l|}{ Mother's education } \\
\hline Up to grade $8^{*}$ & 179 & 21 & 11.7 & 75 & 41.9 & 73 & 40.8 \\
\hline Grade $9-11$ & 684 & 80 & 11.7 & 310 & 45.3 & 297 & 43.4 \\
\hline Grade 12 and above & 239 & 32 & 13.4 & 95 & 39.7 & 89 & 37.2 \\
\hline $\mathrm{p}$-value & & & 0.778 & & 0.290 & & 0.523 \\
\hline \multicolumn{8}{|l|}{ Father's education } \\
\hline Up to grade $8^{*}$ & 367 & 39 & 10.6 & 163 & 44.4 & 163 & 44.4 \\
\hline Grade $9-11$ & 552 & 72 & 13.0 & 248 & 44.9 & 235 & 42.6 \\
\hline Grade 12 and above & 183 & 22 & 12.0 & 69 & 37.7 & 61 & 33.3 \\
\hline p-value & & & 0.545 & & 0.214 & & 0.077 \\
\hline
\end{tabular}

According to survey findings vitamin A deficiency has been identified as a severe public health problem in the study province (Medical Research Institute, 1998). The knowledge of 
the mother regarding the importance of vitamin A was not satisfactory as evident by following responses: only about $74 \%$ of the respondents in the study have heard of the importance of vitamin $\mathrm{A}$ in the diet; about $41 \%$ did not know that vitamin A causes blindness; $58 \%$ did not know that it can cause night blindness; $61 \%$ did not know its link with Bitot's spots; $47 \%$ did not know its effect on disease resistance and $40 \%$ did not know that it causes growth retardation. Table 9 indicates that the majority of the respondents were able to correctly identify dark green leaves $(92 \%)$, yellow fruits $(85 \%)$, yellow-colored vegetables $(82 \%)$ and animal products like egg, fish and meat $(82 \%)$ as good sources of vitamin A. These results indicate that vitamin A rich foods are known to the majority of the population.

\section{Knowledge, attitudes and practices regarding iodine}

The knowledge of the subjects regarding the iodine nutrition was not satisfactory. Although about $74 \%$ of the respondents knew that the goiter was caused by iodine deficiency only $6 \%$ knew that it was food related, $12 \%$ stated that they did not know the cause of goiter while another $6 \%$ said that it was caused by heredity (Table 9 ).

When asked about how the salt in the kitchen was stored, $40 \%$ of the respondents stated that they keep it in a dark colored glass bottle while 32\% replied that it was kept in a white glass bottle. Some $20 \%$ of mothers mentioned that they were using covered coconut shells. From the foregoing it could be concluded that the awareness about iodine is inadequate among the respondent families. However, the prevalence of goiter was reported to be low in the Southern province compared to seven other provinces in the country. According to the National Iodine Nutrition Status Survey (Medical Research Institute, 2006), total goiter rate (grades 1+2) and the median urinary iodine concentration among 6-9 year-old school children in the Southern province were $0.5 \%$ and $145 \mu \mathrm{g} / \mathrm{l}$, respectively. These figures are better than the National average (total goiter rate 3.8\%, median urinary iodine concentration $154 \mu \mathrm{g} / \mathrm{l})$ and indicate that goiter is not a public health significant problem in the province.

\section{Knowledge, attitudes and practices regarding iron}

It was revealed that only $74 \%$ of the mothers have heard or known about anemia as shortage of blood and others (26\%) did not know about it. The majority of the mothers $(59 \%)$ in the study took haematinic (blood-forming) drugs during the last pregnancy and about $41 \%$ had not taken them. Those who took drugs have taken them daily (92\%) as prescribed. The reason given by those who had not taken them was that it gave a bad taste/smell. As shown in Table 9, majority of the mothers knew that iron helps the baby to be healthy (70\%) but only about $16 \%$ knew that iron tablets reduce anemia/iron deficiency. Yet another $11 \%$ of mothers did not know the importance of iron/ folic tablets during pregnanc).

About $7 \%$ percent of mothers in the entire sample were taking tea or coffee with meals. Mothers knew that taking tea or coffee just after main meals was not good. However, regarding fruit consumption the majority (84\%) stated that they eat when fruits were available and only $16 \%$ had the correct practice of taking fruits with main meals (Table 9). Whether this was due to ignorance or the unavailability of fruits at the correct time, need to be explored. 
Table 9. Mothers knowledge and practices regarding micronutrients

\begin{tabular}{lccc}
\hline Variable & \multirow{2}{*}{ Number responded } & \multicolumn{2}{c}{ Yes } \\
& Number & Percentage \\
\hline Foods rich in vitamin A & $\mathbf{8 0 2}$ & 735 & 92 \\
Dark green leaves & & 680 & 85 \\
Yellow fruits & & 656 & 82 \\
Dark yellow vegetables & $\mathbf{1 1 0 2}$ & 656 & 82 \\
Eggs/meat/fish & & 819 & 74 \\
Causes of goiter & & 69 & 06 \\
Iodine deficiency & & 30 & 03 \\
Food related & & 32 & 03 \\
Contamination of food/water & $\mathbf{1 1 0 2}$ & 70 & 06 \\
Pregnancy & & 528 & 48 \\
Hereditary & & 173 & 16 \\
Iron folic acid tablets & $\mathbf{1 0 9 9}$ & 767 & 70 \\
Increase strength & & 72 & 07 \\
Reduce anaemia/iron deficiency & & 1027 & 93 \\
Help baby to be healthy & & & \\
Time of taking tea/coffee & $\mathbf{1 0 9 9}$ & 175 & 16 \\
Just after main meals & & 924 & 84 \\
Not after meals & & & \\
Time of eating fruits & & \\
With main meals & & & \\
When available & & & \\
\hline
\end{tabular}

\section{Mothers' knowledge regarding handling a sick child}

The knowledge and practices of the mother regarding safeguarding the health and nutrition of the sick child were not satisfactory. Only a small percentage (19\%) of the mothers knew that special attention was needed on feeding and that the child should be encouraged to have more food during illness. Some mothers (28\%) reported giving home treatments and bringing the child to the healthcare professional when the condition is severe (Table 10).

\section{Management of diarrhoea}

As reported by mothers, home-made fluids (36\%), drugs (33\%) and ORS packets (24\%) were the treatments given for the management of diarrhea in children. The child feeding practices during diarrhoea is given in Table 11.

Mothers' knowledge on the management of diarrhoea in children was not satisfactory. During diarrhoea, $30 \%$ of children had received less breast milk or no breast milk at all while liquids were restricted for $35 \%$ and eating was restricted for $40 \%$ of the children by their mothers. 
Table 10. Mothers' knowledge regarding handling a sick child $(n=1102)$

\begin{tabular}{lrc}
\hline Variable & \multicolumn{2}{c}{ Yes } \\
Feeding during illness of the child: & Number & Percentage \\
$\begin{array}{l}\text { Food should be restricted } \\
\text { No special attention is needed on feeding }\end{array}$ & 07 & 01 \\
$\begin{array}{l}\text { Child should be encouraged to have more food } \\
\text { Handing a sick child: }\end{array}$ & 208 & 80 \\
$\begin{array}{l}\text { Immediately the child should be brought to a healthcare } \\
\text { professional with or without home treatment }\end{array}$ & 564 & 51 \\
$\begin{array}{l}\text { Monitor the condition of the child first and the child - } \\
\text { brought to a healthcare professional }\end{array}$ & 308 & 28 \\
$\begin{array}{l}\text { Home treatment given and child brought to a healthcare- } \\
\text { professional when the condition severe }\end{array}$ & 230 & 21 \\
\hline
\end{tabular}

Table 11. Child feeding practices during diarrhoea $(n=1102)$

\begin{tabular}{lcccc}
\hline Feeding practice & $\begin{array}{c}\text { Less than } \\
\text { usual }(\boldsymbol{\%})\end{array}$ & $\begin{array}{c}\text { No change } \\
(\boldsymbol{\%})\end{array}$ & $\begin{array}{c}\text { More than } \\
\text { usual (\%) }\end{array}$ & $\begin{array}{c}\text { Not given at } \\
\text { all (\%) }\end{array}$ \\
\hline Breastfeeding & 05 & 65 & 05 & 25 \\
Quantity of drinks given & 15 & 40 & 25 & 20 \\
Quantity of food given & 25 & 45 & 15 & 15 \\
\hline
\end{tabular}

\section{Knowledge and practices regarding child feeding}

Mothers' knowledge and practices regarding breastfeeding and complementary feeding were satisfactory as shown by the data in Table 12 .

Table 12. Knowledge and practices regarding child feeding $(n=1102)$

\begin{tabular}{lcc}
\hline Specific knowledge /practice & No. of families & Percentage \\
\hline Knowledgeable about exclusive breastfeeding period & $\mathbf{9 0 7}$ & $\mathbf{8 2}$ \\
Breastfeeding started within 1 hour after delivery & $\mathbf{9 5 0}$ & $\mathbf{8 6}$ \\
Knowledgeable about the value of colostrums & $\mathbf{1 0 3 6}$ & $\mathbf{9 4}$ \\
Breastfeeding duration more than 6 months & $\mathbf{1 0 0 3}$ & $\mathbf{9 1}$ \\
Introduction of water after the 4 $4^{\text {th }}$ month & $\mathbf{8 5 6}$ & $\mathbf{7 8}$ \\
Introduction of other liquid foods at the correct time & $\mathbf{7 9 9}$ & $\mathbf{7 3}$ \\
Introduction of semisolid foods at the correct time & $\mathbf{9 0 5}$ & $\mathbf{8 2}$ \\
\hline
\end{tabular}

\section{CONCLUSIONS}

Of the children under-5 years old, only $41 \%$ had satisfactory nutritional status and $59 \%$ had some form of malnutrition. Majority of them were wasted $(42.7 \%)$. The prevalence of underweight and stunting among these children were $41.2 \%$ and $11.8 \%$, respectively. Low birth weight had a positive relationship with the current undernutrition of the child.

Mothers were better educated than fathers in this community. Parental educational status was not associated with the prevalence of underweight or low birth weight in children. 
The knowledge about micronutrients (vitamin A, iron and iodine) was not adequate. The knowledge of the mother about management of diarrhoea and feeding during illnesses was unsatisfactory while that of breastfeeding and complementary feeding was satisfactory.

\section{ACKNOWLEDGEMENT}

The authors acknowledge World Vision Lanka for the assistance given to conduct this survey.

\section{REFERENCES}

Annual Health Bulletin (2006). Department of Healthcare and Nutrition, Sri Lanka.

Caulifield, L.E., de Onis, M., Blossner, M and Black, R.E. (2004). Undernutrition as an underlying cause of child deaths associated with diarrhoea, pneumonia, malaria, and measles. Am. J. Clin. Nutr. 80:193-8

CDC (2000). Growth Charts. Centre for Disease Control and Prevention, National Center for Health Statistics, United States of America.

de Onis, M. and Blossner, M. (1997). WHO global database on child growth and malnutrition. WHO, Geneva, 710p

de Onis, M., Frongillo E. A. and Blossner, M. (2000). Is malnutrition declining? An analysis of changes in levels of child malnutrition since 1980. WHO Bulletin 78: 1222-33.

Department of Census and Statistics in collaboration with Ministry of Health (2008). Nutritional Status of Preschool Children in Sri Lanka. Demographic and Health Survey 2006/7, Sri Lanka.

Khan, A. A. and Bano, N. (2007). Child Malnutrition in South Asia. South Asian Survey 14(1): 129-145

Medical Research Institute (1998). Vitamin A Deficiency Status of Children in Sri Lanka 1995/96. Ministry of Health and Indigenous Medicine, Sri Lanka.

Medical Research Institute (2006). Iodine Nutrition Status in Sri Lanka 2005, Department of Healthcare and Nutrition, Sri Lanka.

Wikramanayake, T.W. (1997). Food and Nutrition $3^{\text {rd }}$ ed. Hector Kobbekaduwa Agrarian Research and Training Institute, Colombo. 